\title{
Ligação Química
}

\author{
por Alberto Romão Dias com a colaboração de J. J. R. Fraústo da Silva, M. J. \\ Calhorda, L. F. Veiros e M. M. Salema \\ IST Press, Lisboa, 2006, 656 pág., €35,00 ISBN 972-8469-49-7
}

C A R LOS C. ROM Ã O*

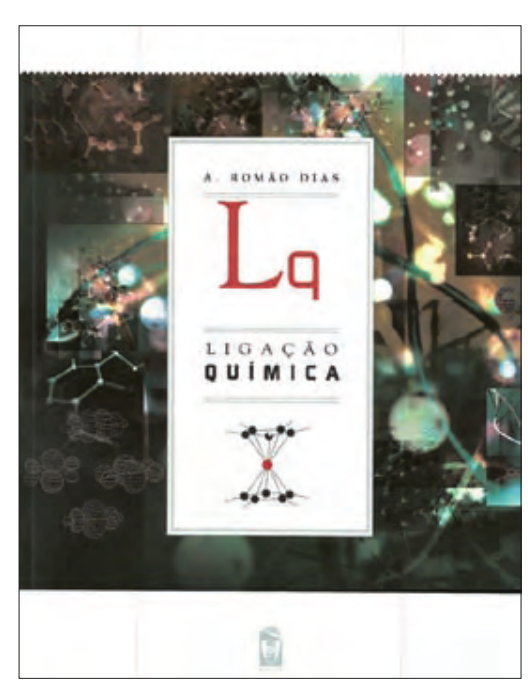

Ao folhear pela primeira vez esta obra não pude evitar pensar: "Até que enfim, saiu!"

Não foi necessário folheá-la para adivinhar a maior parte do seu conteúdo que me acompanhou durante toda a minha carreira de Químico e, em particular, enquanto docente de Química no IST de 1971-1997. Durante este período fui testemunha privilegiada da sua génese, do seu desenvolvimento e amadurecimento, com excepção das actualizações lavradas pelos colaboradores do Professor Romão Dias, todos eles meus antigos colegas (e um deles Professor) no ensino destas matérias.

Sendo apologista do uso generalizado de literatura primária e secundária em língua inglesa como parte integrante e maioritária da formação de cientistas e técnicos capazes de actuar no mundo

\footnotetext{
* Instituto de Tecnologia Química e Biológica Universidade Nova de Lisboa (ccr@itqb.unl.pt)
}

globalizado da Ciência, sempre tive a noção de que o ensino de certas matérias de natureza absolutamente fundamental e formativa tem enormes vantagens se feito na língua materna, neste caso o Português. A estruturação de conceitos novos e estruturantes para toda uma carreira não precisa de ser confundida pela aprendizagem simultânea de um novo tipo de uso (linguagem e calão científico) duma língua estrangeira.

É nestas áreas que reside o maior valor desta obra. No que respeita à estruturação de conceitos ela foi aperfeiçoada durante três décadas para introduzir os estudantes do $1 .^{\circ}$ ano nos fundamentos da ligação química não só em moléculas mas também em compostos iónicos e metais. O que se aprende aqui nunca mais se pode esquecer e estará, duma forma ou doutra, sempre presente na actividade real de qualquer Químico, Bioquímico, Engenheiro Químico ou Biotecnólogo. Estou seguro de que há vários milhares de exestudantes do IST que o poderão corroborar apesar de terem usado uma forma graficamente muito menos apelativa: as velhas "folhas". No que respeita ao uso do Português é bem patente a forma como este texto marcou a linguagem da Química em Portugal.

Despido de "fogos de artifício multimédia" hoje em dia comuns à maioria dos textos introdutórios de Química, este texto é de grande concisão e clareza concentrando a sua mensagem no que é essencial e, normalmente, em poucas mas certeiras palavras. Como sempre dei aulas a "preto e branco" não posso deixar de ficar agradado com o estilo gráfico usado, cuja contenção e elegância ajuda a focar a atenção no que interessa: o texto e os conceitos que exprime.

Pode ser que não seja o livro de mais agrado para os que encaram a aprendizagem da Química como um "frete". Mas é, seguramente, o texto que Ihes permite verem-se livres do dito "frete" duma forma mais rápida e eficaz: é um texto altamente económico e de "alto valor calórico" onde se pode aprender depressa e bem. Pela certa!

Para os que fazem da Química uma profissão este texto é uma "apólice de seguro" para a vida onde poderão recorrer para, em muito pouco tempo, refrescarem ideias, conceitos ou exemplos já vagos na memória. Por mim, tenho-o feito toda a vida (usando as "folhas" já bem "sebentas", claro), e continuarei a fazê-lo, apenas com mais "luxo" e maior necessidade, que a idade não perdoa...

Por isso, faço votos de que este livro venha a ser adoptado de forma generalizada no ensino universitário português (e porque não em Língua Portuguesa? Ousemos ousar...) e consiga finalmente galgar os portões da "Alameda" como já há muito tempo merecia (e devia) ter feito. De facto, o maior (para mim, o único) defeito deste livro reside na sua data de edição: se onde se lê "IST Setembro 2006" (p. V) se tivesse podido ler "IST, Setembro de 1980 ou lá perto..." muitos mais poderiam ter usufruído duma obra arquitectada e acarinhada por alguns dos mais destacados expoentes da Química Portuguesa. Os caloiros e os respectivos professores estão de parabéns com esta edição tão aguardada. 